\title{
The Pattern of Translation Strategies of Idiomatic EXPRESSION IN COMICS
}

\author{
Rahmat Wisudawanto, Firdhaus Hari Saputro Al Haris \\ Sahid Surakarta University \\ wisudawanto@gmail.com
}

\begin{abstract}
This article focuses on translation strategy of idiom in comic Garfield Goes to and its translation. It is expected to identify translation strategies and to know the pattern of translation strategies in translating the idiomatic expression. This research belongs to descriptive qualitative. The source of data is a comic entitled Garfield Goes to Waist and its translation Garfield Mengurangi Berat. Whereas, the data are all of idioms found in the comic. This research applies total sampling technique since the samples are all of data which are found in the source of data. The result of the analysis shows that there are four strategies used by the translator in translating idioms. Meanwhile, the pattern of strategies indicates that Translation by Paraphrasing is dominant strategy. Besides, the others strategies are translation Using an Idiom of Similar Meaning but Dissimilar Form, Translation by Omission and Using an Idiom of Similar Meaning and Form respectively.
\end{abstract}

Keywords: Pattern, Translation Strategies, Idiomatic Expression, Comic

\section{INTRODUCTION}

Translating literature books is not similar to translating academic books. In translating literary works, a translator is expected to be able to produce translations which give the same effect on his reader as it is gotten by readers of the original. Newmark states that there is a wide but universal agreement that the main aim of the translator is to produce as nearly as possible the same effect on his readers as was produced on the readers of the original (1981:10). Moreover, in translating a comic, a translator also faces some problems such as the ones related to the language characteristics of a comic and the limited space of the text. Thus, an appropriate strategy is required to transfer the message as accurately as possible.

Meanwhile, the development of English language signed by the use of idiom makes translation of idiomatic expression become a challenge for a translator (Seild and Mordie, 1980). The term of idioms refers to a phrase or sentence whose meaning is not clear from the meaning of the individual words must be learnt as whole units" (Hornby, 1995; Fernando, 1996). Thus, idiom is a phrase or sentence which the meaning cannot be seen from the words which arrange it. The meaning, however, can be seen from the whole unit of words which arranges the idiom. In details, Mona Baker (1992:63) states that

Idiom and fixed expression are at the extreme end of the scale from collocation in one or both of these areas: flexibility of patterning and transparency of meaning, they are frozen patterns of language which allow little or no variation in form and, in the case of idioms, often carry meaning which cannot be deduced from their individual components.

Meanwhile, one of translation strategies in translating idioms is proposed by Baker (1992). She states that there are four strategies namely: Using an Idiom of Similar Meaning and Form, Using an Idiom of Similar Meaning but Dissimilar Form, Translation by Paraphrasing, Translation by Omission.

\subsection{USING AN IDIOMS OF SIMILAR MEANING AND FORM}

In this strategy a translator attempts to find out not only the idiomatic expression in the target language which has similar meaning but also equivalent lexical items. In other word, the implementation of the strategy focuses to achieve both of equivalents in meaning and lexical items.

\subsection{USING AN IDIOMS OF SIMILAR MEANING BUT DISSIMILAR FORM}

This strategy is used when a translator finds the idiom or fixed expression in the target language that has similar meaning with the idiom or fixed expression in the source language but it has different lexical item. 


\subsection{Translation by PARAPHrasing}

Translator uses this strategi since a match idiom cannot be found in the target language or when it seems inappropriate to use idiomatic language in the target text because of differences in stylistic preferences of source and target language. In this strategy, a translator can paraphrase the meaning of an idiom with his own word when there is not a match idiom in target language or the use of idiom in target language is inappropriate.

\subsection{Translation BY OMISSION}

This strategy is usually used by the translator when there is no close match idiom in target language or the meaning of idiom in target language is not easily paraphrased. Besides, the translator can also apply this strategy for stylistic reasons.

Some research related to translation idiom is presented by Adelnia and Dastjerdi (2011); Wicaksono and Wahyuni (2018). Both research analysis translation strategies for translating idiomatic expression. However, they are not presented the pattern of translation strategies; besides, they are not used utterance comic as data so the pattern of productivity of translation idiomatic expression is not shown. The other research is Ayuningtyas et all (2018) that conducted research related to the difficulty in translation idiom. Whereas the research focuses to shows the pattern of translation strategy for idiomatic expression. Since the translation of in idiom in comics is encountered by many problems, it is interesting to discuss. Moreover, when a translator translates idiomatic expression in comics, s/he will face many problems such as the language characteristic of comic, limited space of the text, culture differences, etc. Thus, a translator should be creative in using a particular strategy when s/he transfers a message of idiomatic expression. Besides, by knowing the pattern of translation strategy, it will give highlight in translating idiomatic expression especially in comic.

\section{MATERIALS AND METHOD}

This research uses the descriptive qualitative method. The application of descriptive method is limited not only in collecting data but also in analysing and interpreting of the data (Surakhmad, 1994). It means that in this research, the researcher collected, analysed, and also interpreted the data, then draws conclusion from the data analysis. Furthermore, this research was conducted to find out translation strategies, accuracy, and readability of the translation of English idiomatic expression in bilingual comics entitled Garfield Goes to Waist.

Meanwhile, this research also employed a single embedded case study as it focuses on the certain characteristic of data. (Sutopo, 2002). Therefore, the researcher only wants to focus on the analysis of strategy and quality, especially the accuracy and the readability of the translation of idiomatic expression from English into Indonesian.

The object of this research is bilingual comics entitled Garfield Goes to Waist written by Jim Davis. The comic contains 125 pages and its translation Garfield Mengurangi Berat published by Nexx Media.

In collecting the data, the researcher carried out content analysis. In content analysis, the researcher collected the data of English idiomatic expression and its Indonesian translation from the research object. They were then compared to know the translation strategies. The technique of data analysis in this research is done through the following stages namely: Observing the English idiomatic expression and its Indonesian translation; analysing the strategy applied by the translator in translating idiomatic expression from English into Indonesian. After the analysis was completed, the researcher made classification based on translation strategies; counting the percentage of each classification and drawing the conclusion of the results of the analysis.

\section{RESULTS AND DISCUSSION}

\subsection{TRANSLATION STRATEGIES}

In the analysis, the data could be classified into four classifications: the data translated using an idiom of similar meaning and form; using an idiom of similar meaning but dissimilar form; translated by paraphrasing; and the data which are not translated or which then called translation by omission.

\begin{tabular}{|l|l|}
\hline Strategy of translating English idiom & Quantity of data \\
\hline Using An Idiom Of Similar Meaning And Form & 1 \\
\hline
\end{tabular}




\begin{tabular}{|l|l|}
\hline Using An Idiom Of Similar Meaning But Dissimilar Form & 6 \\
\hline Translation By Paraphrase & 53 \\
\hline Translation By Omission & 2 \\
\hline
\end{tabular}

Table 1: Distribution of Translation Strategies

Moreover, the detailed explanation about each category is presented in the following part:

\subsubsection{USING AN IDIOMS OF SIMILAR MEANING AND FORM}

According to Baker (1992) the strategy of using an idiom of similar meaning and form involves using an idiom in the target language which conveys roughly the same meaning and consists of equivalent lexical items.

There is only 1 data which is translated by using an idiom of similar meaning and form. The details analysis can be explained as follows.

ST: This is it, little buddy. Today I start weight training and take my first step toward hunkhood!

TT: Akhirnya, teman. Hari ini aku mulai latihan pembentukkan tubuh dan mengambil langkah pertama menuju tubuh yang kekar.

This idiom actually comes from English idiomatic expression take a step which means act in particular way (Fernando, 1996). In the example above, the translator translates the idiomatic expression take my first step into mengambil langkah pertama. In Indonesian, mengambil langkah pertama is considered to be idiom which means start to do something. Moreover, the English and the Indonesian idioms have not only similar meaning but also similar lexical items because if the Indonesian version mengambil langkah pertama is translated back into English version, it can be take my first step. Therefore, the strategy used by the translator in translating the English idiomatic expression take my first step into Indonesian is Using an Idiom of Similar Meaning and Form.

\subsubsection{USING AN IDIOMS OF SIMILAR MEANING BUT DISSIMILAR FROM}

The implementation of this strategy due to translator, in translating idiom, is often possible to find an idiom in the target language, which has a similar meaning but consists of different lexical items.

ST: Well, look on the bright side

TT: Yah, cobalah melihat sisi baiknya

According the Oxford Advanced Learner's Dictionary bright side means to be cheerful or hopeful about in spite of difficulties. In the example, the idiomatic expression bright side is translated into sisi baiknya. The translator does not translate idiom bright side by expressing the meaning into Indonesian, but he uses idiom which has similar meaning but consist of different lexical item. The expression sisi baik is an idiom and if it is translated back into English it would be good side. It means that translation strategy used by translator in translating idiomatic expression bright side into sisi baiknya belongs to Using an Idiom of Similar Meaning but Dissimilar Form.

\subsubsection{TRANSLATION BY PARAPHRASING}

Translation by paraphrase is applied when a match idiom cannot be found in the target language. It also can be used when it seems inappropriate to use idiomatic language in the target text because of differences in stylistic preferences of source and target language. The analysis shows that almost all the data translated using this strategy. It is about 53 from the total data or $85.48 \%$ of the total data translated by using this strategy. Some of the data showing this tendency can be seen in the following part.

ST: I wish Jon would get off my back

TT: Aku ingin Jon menyingkir dariku

According to NTC's American Idioms Dictionary get off means to escape or avoid punishment, to leave, to depart. Meanwhile, According to the Oxford Advanced Learner's Dictionary get off means escape or nearly escape punishment. In translating idiom get off into menyingkir, the translator straightly expresses its Indonesian meaning. It is due to the fact that there is no Indonesian idiom expressing the same idea. Therefore, the strategy used by the translator belongs to Translation by Paraphrasing. 


\subsubsection{TRANSLATION BY OMISSION}

This strategy is used by translator since an idiom may sometimes be omitted altogether in the target text. It is due to it has no close match in the target language its meaning cannot be easily paraphrased, or for stylistic reasons.

ST: Remaining absolutely motionless, cats wait for the perfect moment to lunge

TT: Tetap tak bergerak sampai tiba saatnya untuk menyergap

Translation strategy used by the translator in translating idiom wait for is Translation by Omission. According the Oxford Advanced Learner's Dictionary wait for means to stay where one is or to delay acting, whereas Brotowidjoyo (1991) says that English idiomatic expression wait for means await or except. In the example, the translator omits idiom wait for in the target text because the message of that idiom is not significant toward the text. The message of idiomatic expression wait for has been represented in remaining absolutely motionless. Furthermore, by omitted the idiom wait for, it might be easier for the target reader to understand the meaning of the sentence. Consequently, strategy used by translator is classified into classification D.

\subsection{PATTERN OF TRANSLATION STRATEGIES}

The pattern of translation strategies will show the frequency of translation strategies used in translating idiomatic expression. It also shows the dominant strategy used by translator. The researcher bases this analysis on the theory proposed by Mona Baker (1992). This theory is chosen since it encompasses some strategies to translate idiomatic expressions of the source language into target language that are relevant to the analysis.
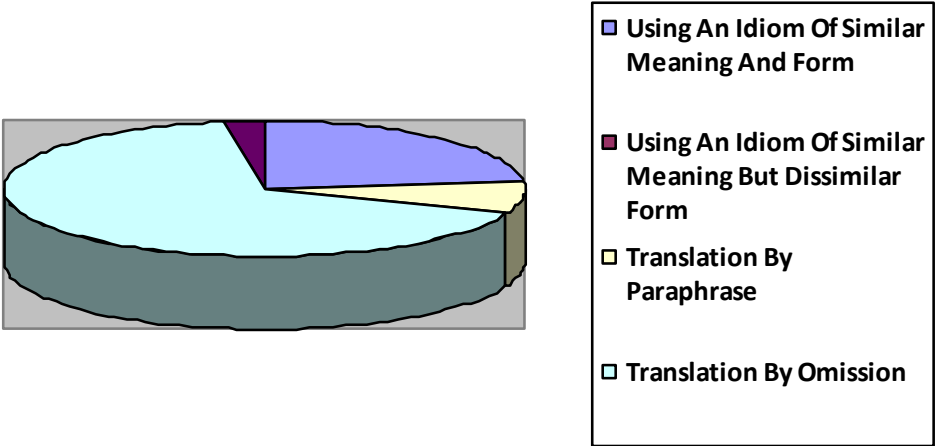

\section{Figure 1: Pattern of Translation Strategies}

The figure 1 shows pattern translation strategy for translating idiom. It is clearly seen that Translation by paraphrasing is the dominating strategy. In the fact, 53 data $(85.48 \%)$ from the total data in this research are translated by Paraphrasing. In other words, majority of idiomatic expression in this research belongs to Translation by Paraphrasing. Meanwhile, Using Similar Meaning but Dissimilar Form is the most frequently strategy used by translator after Translation by Paraphrasing. The researcher found 6 data which belong to this strategy or 9.67\% Using Similar Meaning but Dissimilar Form strategy.

The other strategy used by translator in translating idiomatic expression is Translation by Omission. In this research, there are 2 data (3.22\%) from the total data are classified into this strategy. Finally, in this research, the researcher only founds one data $(1.61 \%)$ data which belongs to translation by using similar meaning and form. It is datum number 054 .

\section{CONCLUSION}

Based on the result of the analysis, the translation strategies employed by translator in translating idiomatic expression in comic entitled Garfield goes to waist are translation using an idiom of similar meaning and form, translation using an idiom of similar meaning but dissimilar form, translation by paraphrasing, and translation by omission. Meanwhile the pattern of strategies shows that the dominated strategy is translation by paraphrasing and using an idiom of similar meaning and form is the most rarely strategy implemented. It is due to the fact that the implementation of translation by paraphrasing is easy to be applied when the translator encountered problems of language characteristic and limited space in 
comic while the rarely applies strategy of using an idiom of similar meaning and form because every language has different productivity in produce the idioms.

\section{REFERENCES}

Arikunto, S. (2011). Prosedur Penelitian: Suatu Pendekatan Praktik. PT Rineka Cipta. Jakarta.

Adelnia, A \& Dastjerdi, H V. (2011). Translation of Idioms: A Hard Task for the Translator. Theory and Practice in Language Studies, Vol. 1, No. 7, pp. 879-883

Ayuningtyas, D P, et all. (2018). Students' Difficulties In Translating Idiomatic Expression From English Into Indonesian. Presented in 2nd English Language and Literature International Conference (ELLiC) Proceedings Vol. 2, 2018

Baker, M.(1992). In Other Words : A Coursebook on Translation. London: Routledge

Brotowidjoyo, M.D, (1991), Essential Idioms in English, Yogyakarta: Liberty

Davis, J. (2004). Garfield goes to waist. Bilingual comics. Jakarta : Nexx Media

Fernando, C. (1996). Idioms and Idiomaticity. Oxford: Oxford University Press

Hornby, A.S. (1995). Oxford Advance Learner's Dictionary. Oxford: Oxford University Press.

Newmak, Peter. (1981). Approach to Translation. Oxford: Penguin Press.

Surakhmad, Winarno. (1994). Pengantar Penelitian Ilmiah: Dasar, Metode, dan Teknik. Bandung: Transito.

Sutopo, H.B. (2002). Metodoligi Penelitian Kualitatif : Dasar Teory dan Terapannya dalam Penelitian. Surakarta : Sebelas Maret University Press.

Wicaksono, D B \& Wahyuni, E. (2018). An Analysis Of The Strategies Used In Translating Idioms In Indonesia Into English Found In Indonesian Legends. Celtic: A Journal of Culture, English Language Teaching, Literature \& Linguistics. Volume 3 No 12018 
